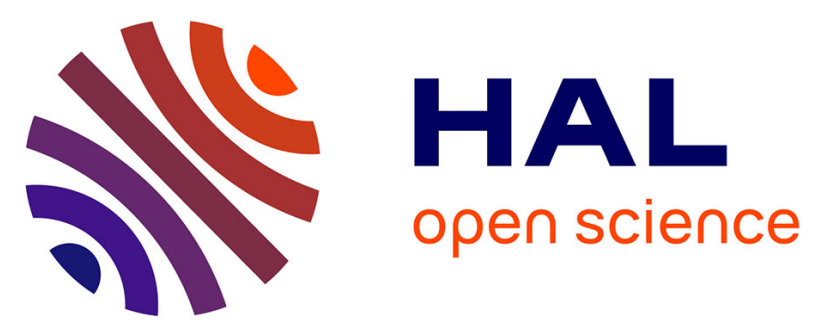

\title{
Direct Puncture of the Superficial Temporal Artery for EVOH Embolization of a Type 3 Arteriovenous Fistula with a Dual Lumen Balloon
}

Frédéric Clarençon, Eimad Shotar, Arnaud Pouvelle, Samuel Mouyal, Stéphanie Lenck, Kevin Premat, Philippe Cornu, Nader-Antoine Sourour

\section{To cite this version:}

Frédéric Clarençon, Eimad Shotar, Arnaud Pouvelle, Samuel Mouyal, Stéphanie Lenck, et al.. Direct Puncture of the Superficial Temporal Artery for EVOH Embolization of a Type 3 Arteriovenous Fistula with a Dual Lumen Balloon. Journal of Neurointerventional Surgery, 2021, 13 (5), pp.493-493. 10.1136/neurintsurg-2020-016351 . hal-03283806

\section{HAL Id: hal-03283806 https: / hal.sorbonne-universite.fr/hal-03283806}

Submitted on 12 Jul 2021

HAL is a multi-disciplinary open access archive for the deposit and dissemination of scientific research documents, whether they are published or not. The documents may come from teaching and research institutions in France or abroad, or from public or private research centers.
L'archive ouverte pluridisciplinaire HAL, est destinée au dépôt et à la diffusion de documents scientifiques de niveau recherche, publiés ou non, émanant des établissements d'enseignement et de recherche français ou étrangers, des laboratoires publics ou privés. 


\section{Direct Puncture of the Superficial Temporal Artery for EVOH Embolization of a Type 3 Arteriovenous Fistula with a Dual Lumen Balloon}

Frédéric Clarençon, MD, PhD 1, 2,3, Eimad Shotar, MD ${ }^{3}$, Arnaud Pouvelle, MD 3 , Samuel Mouyal, MD 3, Stéphanie Lenck, MD ${ }^{3}$, Kevin Premat, MD 1,3, Philippe Cornu, MD, PhD 1, 4, Nader-Antoine Sourour, MD ${ }^{3}$

1. Sorbonne University. Paris. France

2. GRC BioFast. Paris VI University. Paris. France

3. APHP. Pitié-Salpêtrière Hospital. Department of Neuroradiology. Paris. France.

4. APHP. Pitié-Salpêtrière Hospital. Department of Neurosurgery. Paris. France.

Corresponding author:

Pr Frédéric Clarençon (MD, PhD)

Department of Neuroradiology. Pitié-Salpêtrière Hospital.

47, Bd de l'Hôpital. 75013. Paris. FRANCE

Tel: + 33142163599

Fax: +33142163595

e-mail: fredclare5@gmail.com

Word count: 141

Number of figures: 0

Number of videos: 1

Number of tables: 0

Acknowledgment: none 
Funding: none

\section{Disclosures:}

Pr F. Clarençon reports conflict of interest with Medtronic, Guerbet, Balt Extrusion, Penumbra (payment for readings; non-related to the study), Codman Neurovascular and Microvention (core lab; non-related to the study).

Dr Nader-Antoine Sourour is consultant for Medtronic, Balt Extrusion, Microvention. The other authors report no conflict of interest concerning the materials or methods used in this study or the findings specified in this paper. The manuscript is not supported by industry. 


\begin{abstract}
Intracranial dural arteriovenous fistulas (dAVFs) may be difficult to treat by endovascular means, especially when the arterial feeders to the fistula are tortuous. Indeed, the usual main feeder to intracranial dAVFs is the middle meningeal artery, which may present very tight loops, often difficult to cross with a microcatheter. Direct puncture of a subcutaneous artery feeding the fistula indirectly via transosseous branches may be a valuable strategic option to overcome this limitation. We report herein the successful embolization of a Cognard type 3 parietal dAVF by direct puncture of the superficial temporal artery under roadmap guidance. The dAVF was subsequently embolized with ethylene vinyl alcohol via a dual lumen balloon, under balloon inflation. We underline in this technical video the potential difficulties and risks of STA direct puncture; and we also stress the risk of delayed scalp necrosis using this technique.
\end{abstract}

\title{
References
}

1. Kim ST, Jeong HW, Seo J. Onyx Embolization of Dural Arteriovenous Fistula, using Scepter C Balloon Catheter: a Case Report. Neurointervention. 2013;8(2):110-4. doi: 10.5469/neuroint.2013.8.2.110.

2. Oh JS, Yoon SM, Shim JJ, Bae HG. Transcranial Direct Middle Meningeal Artery Puncture for the Onyx Embolization of Dural Arteriovenous Fistula Involving the Superior Sagittal Sinus. J Korean Neurosurg Soc. 2015;57(1):54-7. doi: 10.3340/jkns.2015.57.1.54.

3. Watanabe J, Maruya J, Nishimaki K, Ito Y. Onyx Removal After Embolization of a Superior Sagittal Sinus Dural Arteriovenous Fistula Involving Scalp Artery. Surg Neurol Int. 2016; 3(7):S410-4. doi: 10.4103/2152-7806.183518. eCollection 2016.

4. Gobin YP, Pasco A, Merland JJ, Aymard AA, Casasco A, Houdart E. Percutaneous Puncture of the External Carotid Artery or Its Branches After Surgical Ligation. AJNR Am J Neuroradiol. 1994;15(1):79-82. 
Funding Statement: This research received no specific grant from any funding agency in the public, commercial or not-for-profit sectors.

\section{Contributorship Statement:}

Frédéric Clarençon: data collection, manuscript writing and video preparation

Eimad Shotar: data collection, critical review of the manuscript

Arnaud Pouvelle: data collection, critical review of the manuscript

Samuel Mouyal: data collection, critical review of the manuscript

Stéphanie Lenck: critical review of the manuscript

Kévin Premat: critical review of the manuscript

Philippe Cornu: critical review of the manuscript

Nader-Antoine Sourour: critical review of the manuscript 